\title{
Skills development and skills diffusion for telematic services
}

Citation for published version (APA):

Vennekes, M. H. G., \& van Smoorenburg, M. S. M. (1996). Skills development and skills diffusion for telematic services. Researchcentrum voor Onderwijs en Arbeidsmarkt, Faculteit der Economische Wetenschappen. ROA Working Papers No. 5E https://doi.org/10.26481/umarow.199605E

Document status and date:

Published: 01/01/1996

DOI:

10.26481/umarow.199605E

Document Version:

Publisher's PDF, also known as Version of record

\section{Please check the document version of this publication:}

- A submitted manuscript is the version of the article upon submission and before peer-review. There can be important differences between the submitted version and the official published version of record.

People interested in the research are advised to contact the author for the final version of the publication, or visit the DOI to the publisher's website.

- The final author version and the galley proof are versions of the publication after peer review.

- The final published version features the final layout of the paper including the volume, issue and page numbers.

Link to publication

\footnotetext{
General rights rights.

- You may freely distribute the URL identifying the publication in the public portal. please follow below link for the End User Agreement:

www.umlib.nl/taverne-license

Take down policy

If you believe that this document breaches copyright please contact us at:

repository@maastrichtuniversity.nl

providing details and we will investigate your claim.
}

Copyright and moral rights for the publications made accessible in the public portal are retained by the authors and/or other copyright owners and it is a condition of accessing publications that users recognise and abide by the legal requirements associated with these

- Users may download and print one copy of any publication from the public portal for the purpose of private study or research.

- You may not further distribute the material or use it for any profit-making activity or commercial gain

If the publication is distributed under the terms of Article $25 \mathrm{fa}$ of the Dutch Copyright Act, indicated by the "Taverne" license above, 


\section{Skills Development and Skills Diffusion for Telematic Services}

The Regional Learning System for Small and Medium-sized Companies in the Province of Limburg

ROA-W-1996/5E

M.H.G. Vennekens and M.S.M. van Smoorenburg

Research Centre for Education and the Labour Market

Faculty of Economics and Business Administration

Maastricht University

Maastricht, November 1996 


\section{Contents}

Page

1 Intraduction

11 Background

1

1.2 Research question, research method and outline 1

2

2 Description of the region

2.1 Geographical location and population

2.2 Employment figures and economic structure

2.3 Regional policy on labour market and education

2.4 Telematics policy in Limburg

2.5 Summary

3 The learning system in Limburg

3.1 Actors in the learning system 8

3.2 Some contextual aspects of the learning system $\quad 12$

3.3 Summary

4 The learning SME

4.1 Interviews with the business world

4.2 Summary

5 Evaluation

5.1 Public sector

5.2 Education and training system

5.3 Interfirm relationships

5.4 Small and Medium-sized Enterprises 


\section{Introduction}

\subsection{Background}

This report is part of the project on Networks of European Regional Observatories (NEROs), that will be undertaken in five regions across Europe in 1996 and 1997, under the coordination of the Circa group in Dublin'. These regions and research institutes are:

- Wales, Welsh Development Agency, United Kingdom;

- Dublin, Dublin Chambre of Commerce/CIRCA group, treland;

- Pays de la Loire, Chambre Régionale de Commerce et d'Industrie des Pays de la Loire, France;

- Averro. Assoçiaça Universidade Empresa para a Formaçao (UNEFOR). Portugal:

- Limburg. Research Centre for Education and the Labour Market (ROA). The Netherlands.

This project can be seen as a follow up on the skill shortages research. that was performed in some 20 European regions, including the province of Limburg. The work on skills shortages has been started in 1990 (For Limburg Van Dam et al. 1991) and updated in 1993-1994 (Oosterhuis et al. 1994) Its main purpose was to find the existing and potential bottle-necks on the labour market. One of the findings of these projects was, that for practically all regions in the survey. skill shortages existed in the field of Advanced Telematic Services (ATS) Therefore. by means of the NERO project, an attempt is made to gain some understanding of how such skills are generated and diffused in the context of each region. and how these processes of skills generation and diffusion can be accelerated.

Research partners in each of the five regions will provide a report about the leaming infrastructure in their own regions. and the work of the five partners will result into a synthesis report with the title Developing new skills for the use of advanced telematic services The objectives of the NERO-project, as agreed with the European Commission. are to provide

- a methodology for the comparative examination of regional learning infrastructures in the domain of advanced telematic services

- a set of regional profiles as to how the different regional learning intrastructures develop the future skills, required by companies to use these services.

- a set of plans for the development of the regional learning infrastructure to meet the future skill requirements in the adoption of advanced telematic services 
The emphasıs will be. not only on a description of the region's 'learning infrastructure'. but also on an explanation of the situation in the context of the region, in order to be able to make a comparison between regions and to promote the leaming process within regions with the experiences from other regions.

\subsection{Research question, research method and outline}

The scope of this study will be limited to Small and Medium-sized Enterprises (SMEs). because they represent the group with the greatest lag in developing skills for the adoption of advanced telematic services The theory. underlying the repon. has been based on Lundvall's "regional systems of innovation' (Lundvall. 1992), describing the production structure and the institutional set-up (routines and guidelines to production, consumption etc.) of a region as the major determinants of the direction and intensity of learning and innovation The basic idea of Lundvall's theory is that every region has it's own particular 'system of innovation' or 'system of learnings", which is characterized by the following six elements

- internal organization of firms (flow of information, interaction between departments);

- interfirm relationships (for example producer-user interaction).

- role of the public sector (support for innovation, regulations and standards).

- institutional set-up of the financial sector (financial system has an enabling role in innovation):

- R\&D intensity and R\&D organization:

- education and training system.

The research question. following from NERO's objectives, which is addressed in this report is related to Lundvali's theary

- How does the regronal system of learning with regard, to the use of lelematic services work in Limburg?

The answer to this question and the reports from other regions, will be used to answer the main question of the NERO-projecl. Is this system effective in companson to other regional systems. and why? The comparative element across regions will therefore focus particularly on so-called differences in socio-institutional engıneering.

The research method used is a combination of desk research and interviews These interviews were held with representatives of some important actors in developing and diffusing skills for telematic services in Limburg, such as the Provincie Limburg and the Limburg Industrieel Ontwikkelings Fonds. In addition to these organizations eight companies were interviewed in Limburg which fell in the category SME. The sample of companies was 
taken from advertisers on the Internet. For a further explanation of the methodology and interview guidelines see the appendix.

The report is structured as follows. Chapter 2 gives a brief description of the province of Limburg and its socio-economic characteristics. Furthermore, this chapter outlines the telematics policy in Limburg since the mid 1980s. In chapter 3 , a schematic picture of the regional learning system, and its most important actors will be developed. Then chapter 4 will delineate the findings of a survey in a number of SMEs in Limburg. Finally, in chapter 5 some conclusions and recommendations will be summarized.

\section{Description of the region}

\subsection{Geographical location and population}

The province of Limburg has an area of approximately $2,200 \mathrm{~km}^{2}(5.3 \%$ of the Dutch area). and it is remotely located with respect to the economic activity in the Netheriands, which is concentrated in the 'Randstad', the urbanized region in the west of the Netherlands. However, with regard to European economic activity, it is more centrally located than any other Dutch region. It borders Germany over a distance of $198 \mathrm{~km}$ and Belgium over a distance of $125 \mathrm{~km}$. The location of the province is shown in Figure 1. Unsurprisingly, Limburg is oriented towards exports more than the Netherlands on average; $30 \%$ of all companies in the region are involved in exports, which is well above the national average of $19 \%$.

Limburg has a population of 1.13 million inhabitants $(7.3 \%$ of the Dutch population). Over the past few years, mainly due to low birth rates, population has been growing at a lower rate than the Netherlands on average. In 1995 the Dutch population grew by $0.44 \%$ and the population of Limburg by $0.24 \%$. As a result of this, the region is aging more rapidly than the country as a whole (ETIL, 1995). Figure 1 shows the area of the province of Limburg in the Netherlands. 


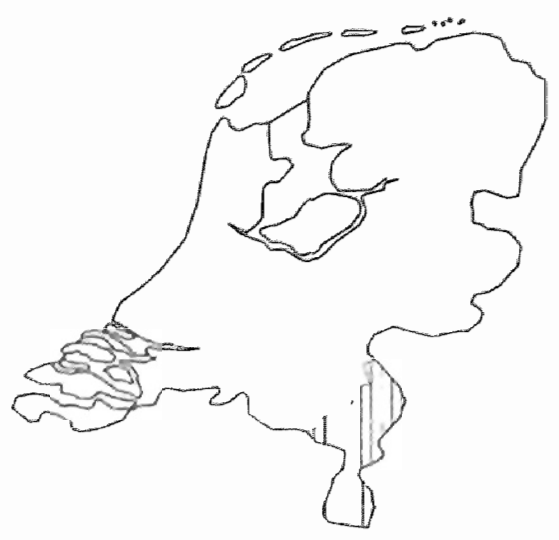

\subsection{Employment figures and economic structure}

During the first half of the century. especially in the southern part of the province, the main economic activity in Limburg was coalmining, until in 1965 the state mines were closed, and national government decided to give Limburg the status of developing region within the Netherlands. Since then, the economic base of the region has shifted radically towards manufacturing and services In 1994. the regional Gross Domestic Product of Dfl 35.2 milliard (ECU 17 mld.) was generated primarily in manufacturing and commercial services Industries Manufacturing companies accounted for $28 \%$, and commercial services for $40 \%$ of regional GDP. On a national level, these figures are slightly different Manufacturing accounts for $21 \%$ and commercial services for $47 \%$ of the national GDP.

This greater concentration in Limburg on manufacturing also appears from employment figures. The employment as a percentage of the working population of the region is presented in table 1 Again. it is obvious that compared to the rest of the country. Limburg can be characterized as an industrial area Al the same time commercial services are far less important for employment in Lımburg than in the rest of the Netherlands

Of the total number of companies in the Netherlands, $6.5 \%$ are based in the province of Limburg. In both Limburg and the rest of the country, $98 \%$ of all companies employ less than 50 workers (CBS, 1994). The relative importance of these 'under 50-companies' for the 
region in terms of employment is $42 \%$, which is relatively high compared to the rest of the country.

Table 1

Employment per economic sector, 1994

$\underset{\%}{\operatorname{Limburg}} \quad \begin{array}{r}\text { Netheriands } \\ \%\end{array}$

Agriculture

manufacturing and construction

2

34

2

Commercial services

Non-commercial services

Source CBS 1995b

World-trade recovery from the latest recession seems to have favoured Limburg in particular with its export-oriented regional economy Growth in 1994 and 1995 was relatively high, but for the moment it seems to level off to the national average. Profitability of SMEs in the region is high, increasing and above national average. In 1994, 90\% of all SMEs (less than 50 employees) were profitable (ETLL. 1995).

\subsection{Regional policy on labour market and education}

Regional policy on the labour market is part of the socio-economic policy of the province Since the early 1980 s this labour market policy has been characterised by a small number of objectives, which have not changed very much since then. and take the general form of stimulation and creation of favourable conditions for the local economy These original objectives are mainly aiming at the demand side of the market (provincie Limburg. 1996).

- Improvement of the labour market (providing information and stimulating co-operation between market parties);

- reinforcement of the educational infrastructure.

education of the unemployed

In 1995. in Ine with national employment pohcy, a fourth objective has been added to the provincial policy. focusing on the hard-to-fill vacancies

The main goal of educational policy us to provide a sufficiently spread and qualitatively good supply of education Attention is focused on secondary education, vocational education and adult education. The overall objective of regional governmental activities in this field is to ensure an effective match between education and the labour market, and as a result of this, provincial government has integrated these two fields of policy last year. 
The regional government executes its policy by subsidzing training projects which are initiated by companies and training institutes. It has been involved in 54 projects during the period of $1992-1995$. in which it spent approximately ECU $4 \mathrm{~min}(12 \%$ of the total value of the projects) A small number of these projects were related to telematics. most of them being intuated by the Technology Centre for Limburg (TCL) Some examples are

- The 'STARTED' project, aiming at the development of a knowledge and training infrastructure to provide SMEs with the means to deal with the demands of new technologies,

- The project 'Networks for best lifelong learning practice in traning for SMEs' The objective of this project is to convince SMEs of the importance of 'lifelong learning for innovative development and as a general strategic business tool.

Another important player in the field of education and labour market policy is the regional employment board (RBA), in which employers, unions and government participate. RBA has a co-ordinating role in labour market policy, operating in a network of training organizations with the objective to improve the supply of skilled labour on the regional labour market Market research among companies provides the information on which the RBA acts to prevent skill shortages, and for the moment, this has resulted in a number of initiatives in the field of engineering and other technical education One of the most important training facilities which are related to RBA is 'Centrum Vakopleiding' which is a practical training centre.

\subsection{Telematics policy in Limburg}

The importance of telematics for the region has been recognized since the late $1970 \mathrm{~s}$ In 1986. provincial government and industry started a joint initiative to promote the development of the market of telematics in the region: Stichting Telematuca Platform Limburg (STPL). This telematics platform had a pioneering objective. From 1986 until 1989 it concentrated on exploring new developments in telematics and promoting a positive attitude towards telematics' (STPL, 1991). It had an important advisory role with regard to regional policy making in 1989, the platform's strategy was changed into initiating concrete projects. informing regional companies, promoting the use of telematic services and creating a network of experts and users of telematics Related with the latter objective was the 'board of participants'. In which ewery interested person from industry. government or knowledge centres could take place

STPL wrote in 1988 its Master plan Telematica Limburg, to serve as a base for regional development policy. The reason for undertaking the Master plan study was to be able to formulate an effective policy that would move the region into a favourable position for future 
economic development. One of the major issues was an analysis of specific user needs in 22 selected (most relevant) sectors of the region's economy. This analysis led to the realisation that a general, abstract policy scenario would be nnadequate for concrete policy measures and during the study the approach was turned around instead of top-down (policy leading to sectoral projects) a bottom-up approach would be followed (sectoral projects leading to provincial policy) A number of proposals for specific projects with or without prionty were formulated and fitted into a framework of general policy This framework consisted of the following elements: infrastructure. education and labour market. internationalisation. public relations. organisational/institutional issues and town and country planning A second issue was to give an overview of the situation and the development of the telecommunications infrastructure in general. in particular the upgrading of networks and replacement of electro-mechanical technology by digital technology. It was shown that Limburg was rapidly developing its digital telephone and data communications networks and in some areas it was quicker than The Netherlands on average However, it was argued by some experts that The Netherlands were weak in the development of telecommunications. compared to other European countries (STPL 1991). For example. in 1991 the number of telephone connections per 1000 inhabitants in The Netherlands was 382, as compared to 718 in France.

When it became clear that the pioneering stage of telematics had been passed and a strong growth of the branch had begun, the STPL was terminated by the end of 1991. In it's last year. STPL has assisted in starting up similar projects in other (geographically and economically remote) areas in The Netherlands. thereby showing that this model of development has served as an example for some other regions in the country.

The end of STPL was the beginning of a period in which the interest for telematics decreased somewhat. As one of the former STPL directors put it 'The hype of telematicspopularity seems to have levelled off around 1991. which is not very surprising. Sudden peaks of public interest in a particular subject usually disappear as suddenly as they occurred. At the moment however, attention is again drawn to the subject, along with the Internet-hype, and the fact that provincial government has gained a new interest in it".

An interesting and important issue in the current policy on telematics development in Limburg is. that it seems to have evolved from telematics-development as an objective in itself, towards telematics-development as a means to renforce the competitive strength of the regional business world. This means in practice that the provincial government attunes its efforts to the demand for skills from enterprises, and that it initiates development of any kind, only when such development is justified economically. The background of this evolution is described in section 3.2 . 


\subsection{Summary}

The province of Limburg is situated in the south-east of The Netherlands, and it is remotely located with respect to the economic activity in Holland. The regional economy depends relatively heavily on manufacturing, and is relatively weak in the area of (commercial) services. Governmental policy to stimulate ATS development has been very active since the 1970 s, and this policy has evolved to an integration into the economic development policy.

\section{The learning system in Limburg}

\subsection{Actors in the regional learning system}

The most important actors in developing and diffusing skills for Advanced Telematic Services (ATS) are presented in figure 2 The figure of actors in the learning system is drawn around the Small or Medium-sized Enterprise. It highlights three factors from Lundvall's theory namely the role of the public sector, the education and training system. and interfirm relationships. The other three factors (institutional set-up of the financial sector, internal organization of firms and R\&D intensity and organization) appeared from the interviews to be less relevant

Figure 2

Actors in the learning system

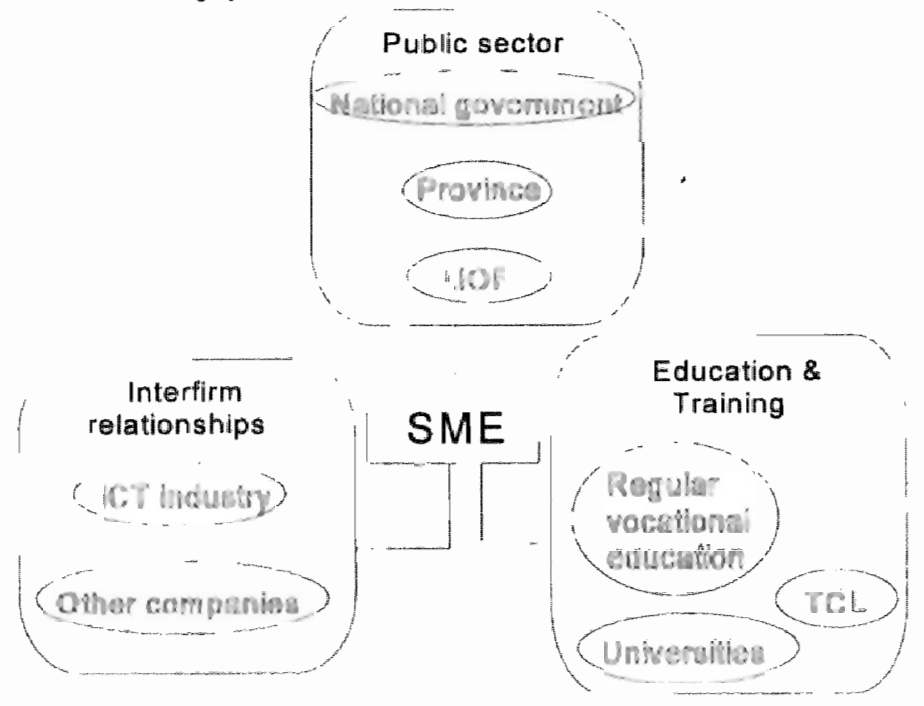


As can be seen, there are four major groups of organisations, playing an important role in skills development and diffusion. The role of the small and medium-sized enterprise will be discussed in chapter 4 . We now focus on the other three actors.

\section{Public sector}

The first group in the figure are the governmental authorities (divided in a national and a provincial level) and their intermediary organisations. The most important issues of governmental policy have already been described in chapter 2. Governmental stimulation is considered to be the most important drive for the development of technology and knowledge-infrastructure, because initiatives from the business world are still scarce. Especially the province's policy seems to be very effective and therefore it has an important positive effect on the region Especially the very strong and effective lobby to attract support and investment from outside the province is still felt to be an important stimulus for the development of Limburg.

LIOF, the development and unvestment bank for the region of Limburg is a so-called government-intermediary Like the overall provincial policy, it can be regarded as a typical result of the historical evolution of the region. which has been characterised by a very unfavourable economical situation in the late "60s and the early "70s.

LIOF is one of the 5 regional development companies which were founded by the national Ministry of Economic Affairs in the 1970s. Although Limburg has lost its status of developing region. LIOF still exists and plays an important role in the region The organisation has three major tasks:

- acquisition of companies from outside the region.

- participation in regional companies to provide them with financial means for investment

- development and innovation Development refers to the initiation of development of five themes which are seen as crucial by the public sector One of these themes is telematics Innovation refers to the funding of innovation projects in medium-sized companes

\section{Education and training system}

The second group is made up of the following organisations the Dutch universities, of which the Technical Universities and (for Limburg) the University of Maastricht are important, the intermediate and higher vocational schools (MBOs and HBOs), as well as the Technology Centre for Limburg (TCL) The latter is a training institute that has been founded by the province and a number of enterprises. Telematics education is concentrated in a small number of $\mathrm{MBO}$ and $\mathrm{HBO}$ schools in Limburg, namely Sittard and Venlo which are both 
technical schools Occasionally they are supported by governmental (provinicial) authorties for educational programs which are felt to be important for the regional knowledge inirastructure, such as telematucs This concentration is part of a governmental policy of forming regional education centres (ROCs). each with ther own specialism. so that knowledge and investments in education will no longer be fragmented among a large number of small institutions.

As said. another, very important actor for telematics development in the province of Limburg is $\mathrm{TCL}$. providing training. advise and support for development to commercial and noncommercial training institutes, as well as to the business world One of the main activities of TCL is the development of and training for new educational technology, such as multimedia, telelearning. and information services These are the main activities in the field of ATS development Other activities such as training for production technology, process technology and laser technology. aim solely at the business world.

\section{Interfirm relationships}

The third group of interest is the busıness world, divided in the Information and Communication Technology industry (ICT). and other companies First the umportance of the relationship with other companies will be briefly outlined, then the ICT Industry and its relationship with SMEs will be described in somewhat greater detail

The category of 'other companies' represents the business relations of the SME in figure 2. which influence the development in the SME These relationships are regarded as perhaps the most important promoter of high technology developments in individual SMEs, because many firms do not start developing new applications (and new skills) before they have seen the example of one of their business relations. Also, the success of communication services depends on its adoption rate. Therefore policy makers employ a model of innovator and follower, in which the innovative company (usually a bigger firm) is supported with pilot projects and a spin-off to less innovative companies is hoped for. if these companies come across the new technologies with their business relatıons. Furthermore, facilities are created to stimulate development among SMEs from the following-category'. to show the possibilities of ATS for specific organisations.

The importance of the ICT industry is obvious: They are both supplier and demander of knowledge. According to policy makers, the ICT industry represent the onty growp of enterprises among SMEs, which exercise a sizeable demand on them for knowledge. At the same time, when these companies supply their clients with an ICT-service, very often they also provide the necessary training to work with the application. The ICT industry can be 
divided in a telecommunication (carrier) industry and an information (telematic services) industry. Although carrier and information services are not always separate in practice, the two branches will be dealt with separately.

\section{Telecommunications industry}

As in most other countries, the provision of telecommunication services in The Netherlands has been regulated by law, giving the national PTT the opportunity to grow as a monopolist in network (carrier) services. Recently however, other suppliers have been admitted to the market to enhance competition.

In the field of mobile communication in Limburg the PTT has recently been joined by its first national competitor. Libertel. Other (potential) competitors are organisations, already having a network for specific purposes at their disposal, and currently attempting or planning to expand their activities towards public telecommunications. Examples are:

- Providers of cable televisian networks;

- NOZEMA (Dutch television and radio broadcasting).

- INMARSAT (Communication with ships via satellites):

- Dutch Railways

In January 1995, 67 companies were active in the exploitation of tele/data communications networks and Value Added Networks (VANs) in The Netherlands only two of which were based in Limburg

\section{Telematic services industry}

With regard to the telematic services industry in the Netherlands, the following classification can be made (Automatiseringsjaarboek, 1995):

- Suppliers of telematics-software (>400 companies)

- Suppliers of telematics-hardware (>400 companies)

- Consultancy in the field of telematics (250 companies)

Like the network providers, there is a strong concentration in the Randstad area For example: Only 7 out of 250 companies in the third category are Limburg-based

One of the experts in the survey stated that although Limburg 'doesn't look bad compared to other regions, it is impossible to keep up with the pace of development in the Randstad area which is economically much more important than remote areas like Limburg' Especially the branch of software development is felt to be a weakness of the ICT industry in Limburg. There are, however some exceptions: A small number of companies are developing and 
producing advanced Decision Support Systems (DSS). some in caoperation with the University of Maastricht. Another example of an advanced ICT application is the information system for public safety which enables local police forces in Limburg. Aachen, MonchenGladbach (Germany). Eupen and Liege (Belgium) to exchange intormation. This project however, is a typical initiative from the public sector. with very limited direct advantages to the business world.

In a survey by Telecommagazine (1996). 32 providers of telematic or telecom services were asked to give their opinion on the importance and the future development of Integrated Services Digital Network (ISDN) and A-synchronous Transfer Mode (ATM) One of the general similarities in their comments was that they expected ISDN to gain importance for the consumer and SME markets. The reason for this is that ISDN is proven and available. and liberalisation of the telecommunications market has forced the PTT to lower its tariffs this year This lower tariff has made one ISDN connection with two channels cheaper than two separate telephone lines In other words: ISDN becomes a competitor for the traditional telephone network, offering possibilities for voice communication in combination with faster data communication, and a number of additional facilities like 'calling line identification, and 'auto call back' ISDN is thought to be an important development for remote access. like connection of remote offices to headquarters, teleworking, telelearning etc.

According to the industry, the greater possibilities of ISDN compared to traditional communication services, in combination with its falling price and its modest requirements for investments in infrastructure, will make it a success within the next five years.

The situation for ATM is somewhat different The technology offers many possibilities but requires enormous investments in physical infrastructure $A$ break-through is therefore not expected in the short run Besides. the target market for ATM are not SMEs but large companes with 'bulk-data transport needs'

\subsection{Some contextual aspects of the learning system}

As already polinted out above, initiatives by private enterprises, particularly SMEs, are scarce. and the most important player in telematics development in the region is the public sector. Adoption and development of Advanced Telematic Services (ATS) in SMEs are very slow processes which have not yet begun for the majority of enterprises. A survey by Statistics Netherlands (CBS, 1995c) shows that by the end of 1993 internal data communication was used by less then $5 \%$ of all Dutch companies and external data communication by less then $4 \%$. Growth was expected to be $30 \%$ for external data communication and $10 \%$ for internal communication between 1993 and 1995 but this will not 
result in adoption rates of more than 6 or $7 \%$ in 1995 Further analysis shows that adoption of advanced services is strongly (positively) related to the size of the enterprise. Therefore the adoption rate for SMEs will even be smaller than $5 \%$

Furthermore, there are some specific issues for Limburg with regard to the infrastructure development, that have shaped the direction of its current policy Regional telematics policy was focused on the development of physical infrastructure in the late 1970 s and early 1980s Limburg was involved in a regional experiment, transforming the relevision-cable network from a one-way- into a two-way network. This experiment would create the possibilities for interactive use of the net. The project however, turned into a financial failure and was prematurely terminated. It is now assumed that the failure of the experiment was caused by a lack of demand for a sophisticated cable network, and its development was therefore useless. This belief has led to a change of course in the policy of the provincial government. Physical infrastructure development is now left to companies like MEGALimburg. the energy distribution company. and the province now focuses on the development of the knowledge infrastructure. The failure of the cable experiment also led to a lower prority for telematics as a development issue in Limburg for some time At the moment ATS are undergong a revival of interest and new initiatives are being undertaken. The province launches new projects from time to time. but they do so with an eye on the market for ATS. The purpose of ATS devetopment policy is to support (the start of) market movements towards high-technology innovation and/or diffusion in other words The provincial government have tried to adapt their policy to the demand for knowledge of the business world For that purpose they have performed a research project that was somewhat sımılar to the 'skills shortages' project. and for the executron of their policy they work with intermediaries, like LIOF and TCL. which act as a connection between public sector and business world

\subsection{Summary}

The learning system in Limburg consists of three major components. Governmental authorties and the intermediary organisations. Which play a role in regional development or regional skilis diffusion are the first component (public sector) The second component is made up of the education and training system. Particularly the technical universities. technical vocational schools, and $\mathrm{TCL}$ are important for skills development and diffusion of telematics. The third component (interfirm relationships) consists of the ICT industry and relationships of SMEs with other (leading) companies. 


\section{The learning SME}

\subsection{Interviews with the business world}

In chapter 3 we focused on three important actors in skills development and diffusion for Advanced Telematic Services: the public sector, the education and training system and interfirm relationships (see figure 2). All these three actors are finked with Small or Mediumsized Enterprises. The way they absorb these ATS-skills is not yet discussed. In order to get a first view on this process, we interviewed representatives of 8 companies in Limburg which fell in the category of SME, and the association of employers in Limburg (LWW). The sample of companies was taken from advertisers on the internet. Companies in the survey were active in the following branches. Manufacturing of roll-down shutters construction, printing and advertising services, copy-services, automation services, administration services, and real estate agencies. The size of the companies in the survey. in numbers of employees, ranged from 2 to 50 . The enterprises were too small to have a personnel manager or an information manager.

The telematic services or technologies which were included in the survey were:

- ISDN (Integrated Services Digital Network):

- ATM (Asynchronous Transfer Mode);

- EDI (Electronic Data Interchange).

- Internal E-mail.

- External E-mail.

- Internet.

Respondents were asked, whether or not they knew each of the Advanced Telematic Services (ATS) mentioned above. and if so, if these ATS were in use for the company. The results are shown in table 2, the first column shows the ATS, the second and third column show the number of respondents who knew and who didn't know each of the services, and the final two columns show whether the companies, answering 'yes' to the first question actually used those services or not.

In accordance with the opinion of representatives from the ICT-industry (see section 3.1). ATM does not seem to be an important technology for the smaller firms. only the biggest (and most advanced) enterprise in the sample and a firm that provides automation services were familiar with ATM. ISDN was somewhat better known but used by only one other firm besides these two. 
Table 2

Familiarity with Advanced Telematic Services

\begin{tabular}{lcccc}
\hline & \multicolumn{2}{c}{$\begin{array}{c}\text { Known? } \\
\text { No }\end{array}$} & Yes & No \\
& Yes & No & & \\
ISDN & 4 & 4 & 3 & 1 \\
ATM & 2 & 6 & 2 & 0 \\
EDI & 2 & 6 & 1 & 1 \\
Internal E-mail & 7 & 1 & 3 & 4 \\
External E-mail & 7 & 1 & 5 & 2 \\
Internet & 8 & 0 & 6 & 2 \\
Other & 2 & 6 & 2 & 0 \\
\hline
\end{tabular}

E-mail and internet are commonly known. although not all the companies indicated that they use them This outcome was somewhat unexpected because the sample of enterprises was taken from advertisers on the internet. and therefore the answer to the question does your company make use of internet'. should have been "yes" for all respondents (2 respondents answered 'no"). One more respondent. of whom an E-mail account was given on the internet. didn't know that he had an account at his disposal The reactions to a surprised remark by the interviewer showed indifference towards the products; in all three cases the owner or an employee of the firm had filled out a form, buying advertising space on the world wide web without a clear strategic objective. and apparently they did not attach great value to it.

An obvious and not very surprising result from the survey was that for many SMEs, especially the smaller ones and the manufacturing enterprises. ATS are still new or even unknown ${ }^{2}$ The two manufacturing companies in the survey used none of the six ATS. and they did not know ISDN ATM and EDI Although this sample of manufacturing companies was too small for conclusive statements about Limburg's manufacturing industry, it did provide some support for the expectation of low penetration in SMEs (see section 3.2) The managers in these companies were very confident about the lack of necessity for their companies to adop: ATS. because they thought ATS could not play a significant role for competition in therr sector of industry. their chents were mostiy private persons who did not work with ATS etther, and the firms themselves were too small to lollow state-of-the-arl technology development They emphasized learning by doing. instead of formal education or training

2. The picture may be even somewhat positively biased because this sample of firms was taken from the internet, and therefore the firms in the sample can be expected to be more familiar with ATS than the average enterprise in the region 
As might be expected, response in the service industry was somewhat more positive towards ATS. Some of these enterprises either have a high interest in efficient flows of information (graphical and advertising industry) or deal with intormation as a part of their profession (accountancy), and are therefore almost naturally involved in ATS. Besides these two factors, there also appeared to be a third factor. especially significant in the smaller companies ( $<20$ employees). ATS development in small companies very often seems to depend to a large extent on the personal interest of the company owner ar one or two employees. They promote automation, and therefore ATS development. When this is the case. skills and knowledge associated with ATS are concentrated in one person. who has learned from magazınes. experience or other autodidact initiatives, motivated by personal interest in the subject For small companies. personal interest in the subject is therefore essential in developing ATS applications because skills are neither generated in the formal system of education nor by any human resource program within the firm. Some of the reasons for this were indicated in the interviews: Small companies are less aware of the training and education possibilities, offered by the organisations which constitute the 'learning system' (see figure 2), but they also have less access to the training programs of these organisations, because SME-training facilities are most often designed for mediumsized, but not for small companies One of the respondents of a small company stated that he had tried to obtain support to develop ATS, but the organisations that constitute the learning system. appeared to be more interested in medium-sized companies for development However, the majonty of respondents had never applied for support of development in any way. because they were simply unaware of the possibilities. and they had never considered finding out what the possibilities were Therefore. skills generation with regard to ATS in small firms is very often dependent on (non-structural) initiatives of people with a personal interest in the subject.

One respondent, who was familiar with the training facilities for ATS in the reglon, gave two different reasons for not needing the training facilities from any of the organisations in figure 2:

1) Training factlities are designed to teach rather general basic skills. while the company needs very sector-specific skills that cannot be provided by the tranning institutes

2) It is feit that it would be safer not to introduce third parties in developing innovative applications that could give the company competitive advantage Therefore. developments of ATS and the skils associated with them, are usually worked out internally or with a client with whom the company wishes to set up the new application involvement of third parties, even if they are state- or semu-state organisations would not be desirable. 


\subsection{Summary}

The firms in the sample were found on the internet, and therefore they were expected to be involved in ATS, more than the average Limburg-based SME. Some firms were indeed involved in the development of ATS, but for some other firms this was not the case. None of the firms, neither the very small, nor the medium-sized ones were involved in learning processes which were initiated, funded or in any other way supported by the organisations which were identified as important players in the learning system, although small and medium-sized firms had different reasons, as described above. The overall picture of skills diffusion for SMEs, particularly the small firms, is one of dependency on personal motivation and initiatives by a very small number of people, rather than structural skills development. intiated by a human resource program of the company or governmental stimulation. The only action that most companies undertake once they have started some form of ATS. is to hire people with at least basic knowledge of computers and communication when they need new personnel

An overall conclusion from the figures on penetration of electronic means of communication (section 32 ) and the interviews in SMEs in Lumburg is that for the moment. ATS is not important enough for the majority of small and medium-sızed companies to demand skills and knowledge from the regional learning system in Limburg. Since the provincial policy has been altered to meet demand for skills from the business world, instead of developing physical communication infrastructure at the provincial government's initiative. demand should be the trigger to regional (skills) dewelopment As a result of a lack of demand. this development is very modest, and even within this modest development the formal learning system does not seem to play the leading role for most SMEs It may however be expected that this role will gain importance when ATS become a part doing business and the need for small and medium-sized enterprises to adopt them, arıses. Then. the demand for skills will probably grow and in the smaller enterprises, it will no longer be the exclusive domain of a small group of self-educated computer experts.

\section{Evaluation}

\subsection{Public sector}

The picture that emerges from this report is one of a region in which policy makers have reached a relatively high level of effectiveness. The economic situation in the past has forced the province to take action in a period in which development of ATS had just started, the evolution of regional development policy is therefore relatively mature, and although 
errors which have been made in the past. have led to a decreased interest and activity by governmental authorities in the late 1980s. advancements on the learning curve have been made and interest in the subject has been undergoing a revival in the past few years.

Intermediary organisations such as LIOF and TCL provide a translation between government and business world. although they are unable or unwilling to reach the small companies. On the one hand, aiming at medium-sized companies is a logical strategy (because these companes are now starting the development of ATS and the skills associated with it), but on the other the survey shows that companies which are small but interested in ATS, are excluded from governmental support and acceleration of regional development of ATS towards small companies may be (unnecessarity) hampered.

Concentration of technology education in one place is another potentual beneficial development for the region and its system of skills development and diffusion (Van Dam et al. 1991) Plans to meet this objectre are made in the form of ROC-formation Information about skills requirements is not available on a structural basis. but RBA and the provincial government are planning to set up an information system. to solve this problem

\subsection{Education and training system}

At the moment a rather strong pressure on education and training system emerges, from both government and business world to act more market-oriented. Therefore it can be expected, that in the near future, schools and training institutes will be forced to merge. and to direct their efforts towards a better monitoring of future market demands. This process already shows in some institutes, where contracts with private enterprises are closed to train personnel Another example of this development is the participation of representatives from the business world in the boards of training institutes. Telematics education does not yet belong to the biggest sectors in the education and training system of Lumburg. (the Dutch technical universities, for example, are all located outside Limburg) Some efforis, however are made by the educational institutes and (modestly) by provincial government to expand and reinforce it

\subsection{Interfirm relationships}

During the interviews in some of the organisations which are a part of the learning system respondents indicated that the relationship with other companies, be they suppliers, clients or competitors, is still by far the most important way for companies to get in touch with ATS, and to become interested and to adopt an application. A well known example is the pressure that large companies exercise over their (smaller) suppliers and clients to adopt applications 
such as EDI. Pressure by the market was found to be a motive to adopt some form of external data communication for $61 \%$ of the total number of enterprises having such applications (CBS, 1995c). Plans from the public sector to benefit from spin-off effects from innovations in 'advanced' companies, by means of support for pilot projects, and enhancement of awareness amongst 'less advanced' companies were therefore expressed.

\subsection{Small and Medium-sized Enterprises}

The learning SME in Limburg which has been described in chapter 4 , is a phenomenon which exists only on a very small scale. Development and diffusion of ATS-technology and skills show a pattern of dispersion from large to medium-sized and small companies, and in general they reach service companies before manufacturing companies Limburg is now in a stage where the technology and skills are becoming available to a larger group of users. beyond the experts in multinational companies. This development however. still seems to be limited to companies with a certann size, in a small number of sectors (In other words the technology has reached medium-sized companies. mainly in service sectors). and only few companies have worked out concrete ideas about the use they could have from ATS. In those companies where this awareness is avalable. knowledge is often monopolised in one or two persons, and a strategy to develop skills in a structural way does not exist Recommendations that were already given in the Skill Shortages report (Van Dam et al. 1991), still prove to be problematic

- Explicit human resources development programs were found in none of the companies in the sample.

- cooperation within sectors with regard to tranning is exceptional.

- participation in policy making is restricted to the multinational companies.

provision of information about future demands of skills is umpossible for most SMEs. because in general, these companies do not have a clear picture about their future needs for skills themselves

In general. a concern was expressed with regard to unwillingness. and a lack of interest from the business world (in particular the SMEs), to co-operate in educational matters and to provide facilities for apprenticeships. In the interviews with the companies this unwillingness or lack of interest was also rather evident from the responses which were in many cases, negative on questions regarding education or training items Furthermore. regional policy makers expressed their concern about the development of ATS in small and medium-sized companies. as a result of a lack of initiatives among these companies and the potential future impact of these services on competition in many sectors. As stimulation of private initiative is very difficult for policy-makers, this should be a concern to the regional business world itself. 


\section{References}

CBS (1994). Statistiek van het ondememingenbestand, Sduruitgeverij/CBS-pubtikaties,

Gravenhage

CBS (1995a). Sociaal ecomomische maandstatistiek - November 1995, 's Graventhage. Sdu-uitgewerị' CBS-publikaties, 's Gravenhage.

CBS (1995b), Werken en leren in Nederland 1995, Voorburg/Heerten.

CBS (1995c). Automatiseringsstatistieken, computers and communicatio 1993-1995.

Charles, D. J. Comford, A. Gillespie and R. Richardson, (1994), Socio-economic aspects of a European information space: IT, organisational change and regional development, DG-III -A.5, Brussels.

Dam. JW van. GWM Ramaekers and RKW. van der Vetden (1991). Skil shortages in Lumburg. ROA-R $1991 / 3 E$. University of Limburg. Maastricht

EDP publications, Automatiseringsjaarboek 1995. Breda

ETIL (1995). Limburgse Sociaal Economische Verkenningen 1995/1996. Maastricht

Intercai (1989), Onderzoek schoingskansen in de sector logistiek en vervoer and distributie in het kader van het 150 project Zurd-Lumburg. Geleen

Lundvall. BA (1992). National systems of innovation towards a theory of nnovation and mteractive learning. Pinter publishers, London

Nexus (1995). Advanced communcations for cohesion and regional development. DG-XIII -B, Brus* sels.

Oosterhuis, J.A.J J. and R.K.W. van der Velden (1994). Skills shortages in the 90s. ROA-R- 1994/8E Maastricht.

Porter M (1985), Competitive advantage. Free press New-York

Provincie Limburg (1996), Provinciaal arbeidsmarkt- en onderwijsbeleid. Rapportage 1992-1995 en beleidsvoomemens 1996. Maastricnt

Provincie Limburg and STPL (1988), Masterplan telematica Limburg. Heerlen

STPL (1991). Het is tud voor klenschalige projecten vanult de gebrukerskant. STPL meuws. Kwartaalblad van de Stichting Telamatica Platform Lumburg. Shichting Telematica Platform Limburg. Geleen 1991

Telecommagazine (1996). De rol van ISDN en ATM. VNU business publications. Amsterdam. meı 1996. 


\section{Appendix Methodology and interview guidelines}

Chapters 1 and 2 are largely based on data from CBS and ETIL (see references). Chapters 3 and 4 are based on a number of interviews. Chapter 3 contains the results of interviews, with representatives from organizations, which were identified as relevant for the regional learning system, either from preliminary desk research, or in the course of the survey.

The organizations which appeared to be relevant during preliminary research were:

- Provincial government;

- Limburgs Industrieel Ontwikkelings Fonds (LIOF);

- Regionaal Bestuur voor de Arbeidsvoorziening (RBA);

- The informatics department of the University of Maastricht:

- Adviescentrum Automatisering Limburg (AAL., A government intermediary with an advisory function in the field of telematic services for the business world).

Representatives of the first four organisations were interviewed, AAL had ceased to exist. The respondents indicated Technology Centrum Limburg (TCL) as another important player in the system.

The interviews were held with a guideline that was based on the six factors in Lundvall's learning system. Respondents were asked about their opinion on:

- The evolution of ATS development in Limburg;

- The importance of ATS development for the region and for different sectors of industry;

- The objectives and context of the organisation's own policy;

- The role and importance of other regionally oriented organisations and the relationships between them.

Results of the interviews in companies which were held by telephone are discussed in chapter 4. Twenty-two SMEs were selected from a sample of advertisers on the internet (with the search keys industry and service). Eight companies from the sample responded and they were asked the following questions:

1. How many people does your company employ?

2. Do you know the following services or technologies? If yes, does your company make use of them? If not, have you ever considered using them?

ISDN:

ATM;

EDl:

internal E-mail;

external E-mail 
internet:

other?

3. When did you first adopt applications and why (or why not)?

4. For which purposes are the applications used?

5. How were skills acquired?

Hiring new personnel

-external consultancy

-training personnel (internally/extemally)

6. Have you had any difficulties in finding or training skilled personnel for the application of ATS?

7. Have there been any other developments after the initial adoption? (new applications, new purposes, additional training etc.)

8. Does your company cooperate with other companies to develop ATS applications? Has the relationship with ofher companies influenced the development of ATS in any other way?

9. Has there been any cooperation with, or support from government or semigovernmental organisations (province, LIOF, TCL, RBA, Chamber of Commerce, other?) in developing ATS?

10. Does your firm need additional training or personnel for the use of ATS? What kind of training? Has there ever been an effort to asses skills/training needs in the firm?

11. Does your firm have an explicitly formulated human resource development program? 